\title{
Butterfly Community Conservation Through Ecological Landscape Design in Urban Areas
}

\author{
Orsolya BORSAI*, Mircea VARGA, Adelina DUMITRAȘ, Cornel NEGRUȘIER and Attila KESERŰ \\ University of Agricultural Sciences and Veterinary Medicine Cluj-Napoca, \\ Calea Mănăştur 3-5, 400372, Cluj-Napoca, Romania \\ *)Corresponding author, e-mail: borsaiorsi@gmail.com
}

BulletinUASVM Horticulture 73(2) / 2016

Print ISSN 1843-5254, Electronic ISSN 1843-5394

DOI:10.15835/buasvmcn-hort:12223

\begin{abstract}
Due to urbanization and extension of agricultural areas most of the ecosystems are strongly affected. As a result, preservation of biodiversity becomes more and more important aiming to reestablish the lost habitats of different species (mammals, birds, amphibians, insects etc.). Our research focuses on butterflies which constitute an extremely important group of 'model' organisms. We have identified 15 diurnal 'flying beauties' specific to Cluj area (threatened and unthreathened species) and investigated their ecological requirements that have to be provided for in any landscapes. Furthermore, based on the data collected we have illustrated the utility of our approach by applying it to a hypothetical private garden following the traditional environmental guidelines in our landscape design.
\end{abstract}

Keywords: blooming plants, host plants, landscape design, Lepidoptera, urbanization

\section{Introduction}

Insects are the most important group of animals, representing more than $50 \%$ of terrestrial biodiversity. In contrast to other groups of insects, butterflies are easy to recognize and popular. They use the landscape at a fine scale and react quickly to changes in land use, and to processes such as farmland intensification or habitat fragmentation due to urbanization (Van et al., 2012). In Romania from the total number of lepidopterans (aprox. 4000), 203 butterflies were identified. In the last 30-50 years the number of lepidopterans decreased significantly due to afforestations with exotic species, application of modern agricultural practicies abandoned ing the traditional pesticidefree methods, and the use of "unproductive" lands for constructions (Rákosy, 2013). In this context, creating butterfly gardens in urban areas would diminish the risk of extinction of this flagship taxa.

\section{Aims and objectives}

This research was carried out to identify some lepidopterans, mostly diurnal butterflies, specific to Cluj area. In order to contribute to biodiversity conservation an ecological landscape design was done to call this 'flying beauties' back to city gardens. The main function of butterfly gardens is to provide butterflies a friendly habitat in a matrix that otherwise would be unfriendly because of human domination of the urban landscape.

\section{Materials and methods}

Several field trips were organized to identify the most common and the rarest butterfly species in the surrounding areas of Cluj (Table 1). The plant selection for the new ecological garden design was made according to the ecological requirements of the identified butterflies depending on their developmental stage.

This butterfly garden is green area created especially to attract a diverse community of butterflies. This garden includes nectar plants for adult butterflies, as well as food plants for larvae and caterpillars. In addition, in our new landscape we also used some specific abiotic elements that are indispensable for a butterfly garden such as puddles, rocks and non-flower sources of food. The landscape design softwares used for this 
Tab. 1. Field study results

\begin{tabular}{|c|c|c|c|}
\hline Identified species & Location & Host plants & Nectar plants \\
\hline Aglais urticae & Hoia & Urtica dioica & Buddleja sp., Lantana sp., Tagetes sp., Dianthus sp. \\
\hline $\begin{array}{l}\text { Aphantopus } \\
\text { hyperantus }\end{array}$ & $\begin{array}{c}\text { Apuseni } \\
\text { Mountains }\end{array}$ & $\begin{array}{l}\text { Carex sp., Festuca sp., Poa sp., } \\
\text { Calamagrostis sp., Agrostis sp. }\end{array}$ & Cirsium sp., Sambucus ebulus \\
\hline Araschnia Levana & Florești & Urtica dioica & $\begin{array}{c}\text { Apiaceae, Cirsium avense, Sambucus ebulus, } \\
\text { Eupatorium cannabinum, Ranunculus sp., } \\
\text { Origanum }\end{array}$ \\
\hline Brintesia circe & Tarnița & $\begin{array}{c}\text { Bromus erectus, Festuca } \\
\text { bovina, Poacea }\end{array}$ & Buddleja sp., Lavanda sp., Scabiosa sp., \\
\hline Aglais io & Cluj-Napoca & Urtica dioica, Humulus lupulus & $\begin{array}{c}\text { Echinacea sp., Buddleja sp., Astilbe sp., Sedum sp., } \\
\text { Dahlia sp., Aster sp. }\end{array}$ \\
\hline Limenitis populi & $\begin{array}{l}\text { Apuseni } \\
\text { mountains }\end{array}$ & Populus tremula, P. nigra & $\begin{array}{l}\text { Solidago sp., Phlox sp., Non-flower sources: rotting } \\
\text { fruit, sap, animal droppings }\end{array}$ \\
\hline $\begin{array}{l}\text { Nymphalis vau- } \\
\text { album }\end{array}$ & Băișoara & $\begin{array}{l}\text { Populus sp., Salix sp., Betula sp., } \\
\text { Ulmus sp. }\end{array}$ & Zinnia sp., Asclepias sp., Buddleja sp., Tree sap \\
\hline Vanessa atalanta & Feleac & Urtica dioica & $\begin{array}{l}\text { Buddleja sp., Echinacea sp., Zinnia sp., Lantana sp., } \\
\text { Aster sp. }\end{array}$ \\
\hline Vanessa cardui & $\begin{array}{l}\text { Blue Lagoon } \\
\text { (Aghireșu) }\end{array}$ & Cirsium sp., Carduus sp. & $\begin{array}{l}\text { Salvia sp., Lantana sp., Echinacea purpurea, } \\
\text { Buddleja sp., Aster sp., Zinnia sp., Tagetes sp. }\end{array}$ \\
\hline $\begin{array}{l}\text { Iphiclides } \\
\text { podalirius }\end{array}$ & Sic & $\begin{array}{l}\text { Crategus monogyna, Prunus } \\
\text { spinosa, P. fruticosa, P. tenella, } \\
\text { Rosaceae }\end{array}$ & $\begin{array}{c}\text { Asclepias sp., Phlox sp., Buddleja sp., Lonicera sp., } \\
\text { Hesperis sp., Echinacea sp., Azalea sp. }\end{array}$ \\
\hline Maculinea teleius & Făget & $\begin{array}{r}\text { Molinia caerulea, Epilobium hir } \\
\text { Stachys }\end{array}$ & $\begin{array}{l}\text { rsutum, Sanguisorba officinalis, Lythrum salicaria, } \\
\text { palustris, Prunella vulgaris }\end{array}$ \\
\hline Colias myrmidone & $\begin{array}{l}\text { Apuseni } \\
\text { Mountains }\end{array}$ & $\begin{array}{l}\text { Chamaecytisus ratisbonensis, } \\
\text { Cytisus nigricans }\end{array}$ & $\begin{array}{c}\text { Medicago sp., Trifolium sp., Origanum vulgare, } \\
\text { Scabiosa sp., Dianthus sp., Salvia sp., Aster sp., } \\
\text { Phlox sp. Sedum sp. }\end{array}$ \\
\hline
\end{tabular}

ecological garden wer: Realtime Landscaping Architect, Corel Draw, Sketchup and Lumion for a better illustration of our approach.

\section{Results and discussion}

The results show that if we take into account the ecological needs of diverse butterflies early in the planning stage of our garden, ensuring them a friendly habitat, we can contribute significantly to the preservation of butterfly populations by creating the conditions necessary for their survival. Moreover, the size of the garden and the number of flowering and host plant species used are directly proportional with the number of butterfly species that are attracted to this kind of gardens (Fahrig, 2001).

\section{Conclusion}

In this research, we demonstrated that also landscape architects can have a crucial role in butterfly community conservation, through their abilities to arrange plants in such manner to restore a part of the natural habitat where these small 'flying beauties' can survive against unstoppable urbanization.

\section{REFERENCES}

1. Butterfly Conservation Website (2003). http://butterflyconservation.org/1866/2/showing-butterflies-and-dayflying-moths.html.

2. Di Mauro D, Thomas D, and Larry R (2007). Determining the effect of urbanization on generalist butterfly species diversity in butterfly gardens. Urban ecosystems 10.4:427439.

3. Ellis S, Bourn NAD and Bulman CR (2012). Landscapescale conservation for butterflies and moths: lessons from the UKButterfly Conservation, Wareham, Dorset.

4. Fahrig L (2001). How much habitat is enough? Biological Conservation 100:65-74.

5. Rákosy L (2003). Fluturii diurni din România-Cunoaștere, protecție, conservare. ed. Mega, Cluj-Napoca.

6. Van SCAM., Brereton T, Kirkland P and Warren MS (2012). Manual for Butterfly Monitoring. Report VS2012.010, De Vlinderstichting/Dutch Butterfly Conservation, Butterfly Conservation UK \& Butterfly Conservation Europe, Wageningen. 